GPJI 1 (2) (2017)
http://journal2.um.ac.id/index.php/gpi

\title{
PENGARUH KOORDINASI MATA-TANGAN, DAYA LEDAK OTOT TUNGKAI DAN MOTIVASI BERPRESTASI TERHADAP KETERAMPILAN SMASH
}

\author{
Ayu Widhi Muchlisa ${ }^{1}$ \\ Pascasarjana Universitas Negeri Jakarta
}

\begin{abstract}
Info Artikel Abstrak
Sejarah Artikel:

Diterima September 2017

Disetujui Desember 2017

Dipublikasikan Desember

2017

Keywords:

Koordinasi mata-tangan,

daya ledak otot tungkai,

motivasi berprestasi,

keterampilan smash.

Tujuan penelitian ini adalah untuk mengetahui pengaruh koordinasi mata-tangan, power otot tungkai dan motivasi untuk berprestasi terhadap keterampilan smash Bolavoli. Metode yang digunakan dalam penelitian ini adalah metode eksperimen Teknik pengambilan sampel menggunakan purposive sampling. Hasil penelitian menunjukkan terdapat pengaruh daya ledak otot tungkai terhadap keterampilan smash dengan nilai signifikansi 0,248 . Terdapat pengaruh koordinasi mata-tangan terhadap motivasi berprestasi dengan nilai signifikansi 0,550 , Terdapat pengaruh motivasi terhadap keterampilan smash dengan nilai signifikansi 0,429 . dan terdapat pengaruh daya ledak otot tungkai dan koordinasi mata-tangan terhadap motivasi berprestasi. Kesimpulan dari penelitian ini adalah terdapat pengaruh positif antara koordinasi mata-tangan, daya ledak otot tungkai dan motivasi berprestasi terhadap keterampilan smash atlet klub bolavoli putra se-Kota Pekanbaru

Abstract

The aimed of this study was to determine the effect of eye-hand coordination, leg muscle power and motivation for achievement of smash volleyball skills. The method used in this study is the experimental method Sampling technique using purposive sampling. The results showed that there is an effect of explosive muscle limb power on smash skills with a significance value of 0.248 . There is influence of hand-eye coordination to achievement motivation with significance value 0,550 . There is influence of motivation to smash skill with significance value 0,429 . and there is the effect of explosive muscle limb power and eye-hand coordination on achievement motivation. The conclusion of this research is there is positive influence between eye-hand coordination, muscle limb explosive power and achievement motivation to smash skill athlete club mens volleyball city Pekanbaru
\end{abstract}

(C) 2017 Universitas Negeri Malang

Alamat korespondensi:

E-mail: Ayuwidimuchlisa12@gmail.com

ISSN 0853-5043 (cetak)

\section{PENDAHULUAN}

Olahraga merupakan suatu kegiatan jasmani yang dilakukan dengan maksud untuk memelihara kesehatan dan memperkuat otot-otot tubuh. Kegiatan ini dalam perkembangannya dapat dilakukan sebagai kegiatan yang menghibur, menyenangkan atau juga dilakukan dengan tujuan untuk meningkatkan prestasi. Olahraga menjadi suatu hal yang perlu direncanakan secara matang dari awal perencanaan pembiasaan atlet hinggga bisa mendapatkan hasil yang maksimal. Kegiatan Pembinaan dilaksanakan secara terencana dan berkelanjutan bertujuan untuk menciptakan prestasi di bidang olahraga. 
Permainan bolavoli merupakan salah satu diantara cabang olahraga yang populer dimasyarakat. Hal ini terbukti bahwa bolavoli banyak dimainkan di sekolahsekolah, di kantor-kantor maupun di kampung-kampung. Bolavoli merupakan salah satu cabang olahraga yang sangat berkembang di Indonesia. Olahraga bolavoli termasuk cabang olahraga yang sangat populer dan favorit, bahkan bolavoli menjadi salah satu materi yang diajarkan di sekolah-sekolah, dan biasa dimainkan oleh masyarakat dan para pegawai suatu lembaga bahkan perusahaan. Olahraga bolavoli para remaja memperoleh banyak manfaat, selain untuk menjaga kesehatan serta meningkatkan kesegaran jasmani juga dapat menjadi suatu media untuk berprestasi.

Adapun teknik permainan bolavoli ini yang harus dimiliki terlebih dahulu oleh pemain bolavoli yaitu meliputi service, passing, smash, blocking. Kemampuan seseorang atau atlet dalam/suatu pertandingan atau kompetisi pada dasarnya ditentukan oleh empat faktor yaitu: (1) kondisi fisik, (2) teknik, (3) taktik, (4) faktor mental (psikis). (Syafruddin, 2012:55) Melahirkan seorang pemain bolavoli yang handal selain mempunyai kondisi fisik yang baik, penguasaan kemampuan smash juga sangat diperlukan dalam sebuah permainan bolavoli, semakin baik kemampuan hasil smash yang dimiliki pemain bolavoli maka pencapaian prestasi akan sangat mudah untuk diraih.

Smash tindakan memukul bola yang lurus kebawah sehingga bola akan bergerak dengan cepat dan menukik melewati atas jaring menuju ke lapangan lawan dan akan sulit menerimanya. Penguasaan teknik dasar smash dalam permainan bolavoli sangat penting, keberhasilan suatu regu dalam memenangkan bolavoli banyak ditentukan oleh smash. Sebab smash merupakan cara termudah untuk memenangkan angka, oleh karena itu setiap pemain dalam satu tim harus benar-benar menguasai smash dengan baik, karena smash merupakan serangan utama.

Smash yang baik diperlukan daya ledak otot tungkai yang kuat. Daya ledak otot tungkai berperan penting dalam melakukan loncatan didalam smash. Daya ledak otot tungkai yang baik memberikan pengaruh yang besar terhadap hasil smash dalam permainan Bolavoli. Daya ledak otot tungkai adalah hubungan yang saling mempengaruhi antar otot-otot tubuh, seo- rang atlet yang memiliki daya ledak otot tungkai yang baik akan menunjang kemampuan smash. Selain itu kekuatan dan koordinasi juga mempengaruhi hasil smash, kekuatan yaitu komponen kondisi fisik yang menyangkut masalah kemampuan seseorang atlet pada saat mempergunakan ototototnya, menerima beban dalam waktu kerja tertentu pada saat atlet memukul. Dan koordinasi adalah kemampuan seseorang dalam mengintegrasikan gerakan yang berbeda kedalam suatu pola gerakan tunggal secara efektif pada saat atlet melompat dan memukul bola secara bersamaan.

Berdasarkan observasi penulis terhadap klub-klub pada saat latihan dan bertanding, terdapat kelemahan-kelemahan pada saat smash, seperti bola menyangkut di net, bola keluar daerah lapangan, bola dipukul tidak tepat pada sasaran. Hal ini disebabkan karena kurangnya koordinasi mata-tangan, daya ledak otot tungkai. Disamping beberapa hal diatas kurang didukung oleh daya ledak otot tangan dan bahu, selain itu kurang tepatnya timeing juga kekuatan pada saat smash, kemudian kurangnya koordinasi gerakan pada saat meloncat dan memukul bola di udara. Sehingga bola sering keluar, menyangkut di net dan dapat dengan mudah di block oleh lawan.

Berdasarkan beberapa faktor yang dikemukakan di atas, mendorong penulis untuk melakukan penelitian lebih lanjut mengenai pengaruh antara koordinasi matatangan, daya ledak otot tungkai dan Motivasi berprestasi terhadap keterampilan Smash permainan bolavoli atlet klub putra di Kota Pekanbaru.

Keterampilan adalah kemampuan seseorang dalam melakukan suatu aktifitas secara efektif dan efisien, serta mampu mencapai performa yang baik dalam pencapaian suatu tujuan. Singer sebagai ahli olahraga menjelaskan keterampilan merupakan kemampuan secara efektif suatu pengetahuan dan siap melaksanakannya. (Hanif, 2015: 15). "Motor skills is activities or tasks that require voluntary control over movements of the joints and body segments to achieve a goal". (Magil dan Aderson, 2015:3) Sejalan dengan pendapat tersebut dapat dijelaskan bahwa keterampilan teknik dalam suatu cabang olahraga dapat dijelaskan sebagai hasil dari proses belajar dan berlatih gerak yang secara khusus ditujukan untuk dapat menampilkan mutu tinggi cabang olahraga. (Giriwijoyo dan Sidik, 2012:315) 
Sedangkan, gerak keterampilan adalah gerak yang mengikuti pola atau bentuk tertentu yang memerlukan koordinasi dan kontrol sebagian atau seluruh tubuh yang biasanya dilakukan melalui proses belajar. (Widiastuti, 2015:233)

Berdasarkan pendapat diatas dapat dijelaskan bahwa belajar gerak pada dasarnya merupakan suatu proses pembelajaran gerak yang perlu dipelajari yang memiliki tujuan untuk mengem-bangkan berbagai keterampilan gerak. "motor learning the acquisition of motor skills, the performance enhancement of learned or highly experienced motor skills, or the reacquisition of skills that are difficult to perform or cannot be performed because of injury, disease, and the like. Of interest are the behavioral and or neurological changes that occur as a person learns a motor skill and the variables that influence those changes". (Magil dan Aderson, 2007)

Proses pembelajaran gerak tersebut memiliki beberapa tahapan atau proses agar suatu keterampilan gerak dapat diperoleh dengan efektif dan efisien. "A skill is initially defined as belonging to one of three domains. A domain is simply a category into which similar things can be grouped. A skill is the grouping of skills based upon the underlying capacities most essential for accomplishing them. When defining a skill, our first decision entails deciding whether cognitive, perceptual, or motor capabilities are most necessary to the successful completion of the skill. (Edward, 2010:3)

Smash adalah salah satu keterampilan yang sangat penting dalam permainan bolavoli untuk itu diperlukan tahap pembelajaran gerak agar tercipta smash yang baik serta tepat pada sasaran. Smash adalah salah satu teknik dasar didalam permainan bolavoli yang dilakukan seorang pemain, dengan awalan meloncat memukul bola melewati net ke arah daerah kosong pertahanan lawan dengan pukulan yang tajam dan menukik. Dan tujuannya untuk mematikan pertahanan lawan sehingga mendapatkan poin untuk meraih kemenangan dalam permainan.

Disinilah letak seninya bolavoli, seperti para pecandu sepakbola mendambakan goal yang spektakuler, demikian juga untuk para pecandu bolavoli mendambakan smash yang gemilang (Dieter B, 2005). "The skill that everyone enjoys the most is hitting. Nothing is more dynamic in volleyball than attacking the ball. The ability to terminate a play with a hard-driven spike to end a rally is exhilarating. For the average volleyball fan, the player who hits the hardest is usually the crowd favorite. (Kenny, 2006:61) Dari pendapatpendapat tersebut dapat diartikan bahwa dalam melakukan pukulan smash terdapat beberapa tahap yaitu saat awalan, saat meloncat, saat memukul bola, dan saat mendarat.

Koordinasi merupakan kemampuan untuk menyelesaikan tugas-tugas motorik secara cepat dan terarah yang ditentukan oleh proses pengendalian dan pengaturan gerakan serta kerjasama sistem persyarafan pusat (Syafruddin, 2012:170). Koordinasi juga dapat dijelaskan sebagai suatu kemampuan untuk melakukan gerakan dengan berbagai tingkat kesukaran dengan cepat dan efisien dan penuh ketepatan (Tangkudung, 2012:72). Koordinasi seringkali dikaitkan dengan kualitas gerakan, semakin baik tingkat koordinasi seseorang maka semakin baik pula kualitas gerakan yang ditampilkan. Berdasarkan pendapat di atas dapat dijelaskan bahwa Koordinasi adalah kemampuan mengga-bungkan sistem saraf gerak yang terpisah dengan merubahnya menjadi suatu pola gerak yang efisien. Makin komplek suatu gerakan, maka semakin tinggi tingkat koordinasinya. Koordinasi mata dan tangan adalah kesesuaian antara indera pengli-hatan, gerakan tangan dan ketepatan sasaran.

Kualitas gerakan dalam olahraga dapat menunjukkan tingkat penguasaan teknik-teknik cabang olahraga. Tingkat koordinasi seseorang menentukan terhadap penguasaan suatu keterampilan olahraga. Semua gerak harus dapat dikontrol dengan penglihatan dan harus tepat, sesuai dengan aturan yang direncanakan dalam pikiran seperti memantulkan bola, melempar, menembak, serta menghentikannya, semuanya memerlukan sejumlah input yang dapat dilihat, kemudian input tadi diintegrasikan ke dalam gerak motorik, agar hasilnya benar-benar terkoordinir secara rapi dan luwes.

Daya ledak merupakan salah satu komponen yang penting dalam kegiatan olahraga, karena daya ledak akan menentukan seberapa keras orang dapat memukul, seberapa tinggi melompat, seberapa cepat berlari. Penelitian terdahulu menyebutkan Terdapat pengaruh kombinasi latihan power tungkai terhadap peningkatan keterampilan passing sepakbola. (Dany, 2016). Daya ledak juga dapat diartikan kemampuan untuk meraih suatu kekuatan maksimal dalam waktu singkat Syafruddin, (2012). 
Daya ledak juga dapat dijelaskan sebagai gabungan antara kekuatan dan kecepatan atau pengerahan otot maksimum dengan kecepatan maksimum (Widiastuti, 2015:16).

Power atau daya ledak adalah kemampuan kerja otot (usaha) dalam satuan waktu (detik). Power menyangkut kekuatan dan kecepatan kontraksi otot yang dinamis dan eksplosif serta melibatkan pengeluaran kekuatan otot yang maksimal dalam waktu yang secepat cepatnya. Daya ledak otot (muscular power) adalah kemampuan seorang untuk melakukan kekuatan maksimum, dengan usaha yang dikerahkan dalam waktu yang sependek-pendeknya Sajoto (1988). Setiap gerakan tubuh dalam olahraga pada hakikatnya disebabkan berkontraksinya otot-otot rangka (tubuh) dalam mengatasi beban atau hambatan berupa berat tubuh sendiri seperti gerakan melompat saat melakukan jump shot dan dalam hal ini melibatkan komponen dari otot tungkai.

Tungkai bawah mempunyai tugas yang sangat penting untuk melakukan gerak, gerakan tersebut dapat dilakukan dengan adanya suatu sistem penggerak, yang meliputi otot dan tulang yang terjadi akibat berkontraksinya otot-otot rangka dan saling kerja sama dari sistem rangka dan otot manusia, termasuk sistem persarafan. daya ledak otot tungkai merupakan kemampuan otot atau sekelompok otot tungkai dalam mengatasi tahanan beban atau dengan kecepatan tinggi dalam satu gerakan yang utuh.

Motivasi yaitu dorongan yang timbul pada diri seseorang, sadar atau tidak sadar untuk melakukan suatu tindakan dengan tujuan tertentu (Tangkudung, 2012:28). Motivasi juga dikatakan sebagai suatu pendorong yang mengubah energi dalam diri seseorang kedalam bentuk aktifitas nyata untuk mencapai tujuan tertentu. Motivasi dapat dijelaskan sebagai suatu dorongan yang ada didalam maupun diluar diri, yang akan mengarahkan dan membentuk seseorang agar bisa melakukan suatu aktivitas yang sesuai dengan keinginannya. Motivasi yang harus dimiliki oleh atlet adalah motivasi berprestasi, sebab atlet yang memiliki motivasi berprestasi akan berpacu dengan keunggulan baik keunggulan diri sendiri, keunggulan orang lain, bahkan untuk mencapai kesempurnaan dalam menjalankan tugas latihan maupun kompetisi.
Motivasi berprestasi pada hakikatnya merupakan keinginan, hasrat, kemauan, dan pendorong untuk dapat unggul yaitu mengungguli prestasi yang pernah dicapai sendiri atau orang lain Husdarta (2010). Motivasi berprestasi yang tinggi tidak hanya dibutuhkan dalam pembinaan dan latihan teknik saja, akan tetapi diperlukan dalam semua proses pembinaan dan latihan untuk meraih suatu prestasi. Tanpa dukugan motivasi berprestasi yang tinggi dari seorang pemain bola basket, sulit diharapkan tercapainya prestasi yang diinginkan. Pemain bola basket harus mempunyai motivasi yang kuat untuk mencapai prestasi dengan segala upaya yang dapat dilakukan sampai meraih prestasi tersebut. Meraih suatu prestasi bukanlah perkara mudah untuk itu membutuhkan proses agar semua dapat terealisasikan dengan baik dan disinilah sangat di butuhkan motivasi berprestasi, sebab seseorang yang tidak mempunyai motivasi dalam meraih prestasi maka tidak akan bisa melakukan aktiftas yang mendorong dirinya untuk berlatih lebih maksimal.

\section{METODE}

Metode penelitian yang digunakan dalam penilitian ini merupakan metode kuantitatif asosiatif, dengan pendekatan kuantitatif, metode survei, dan model teknik analisi jalur (path analysis). Path analysis yaitu suatu teknik untuk menganalisis hubungan sebab akibat yang terjadi pada regresi berganda jika variabel bebasnya mempegaruhui variabel tergantung tidak hanya secara langsung tetapi juga secara tidak langsung.

Instrumen tes keterampilan smash bolavoli menggunakan Smash test. Instrumen tes koordinasi mata-tangan menggunakan tes koordinasi mata tangan, selanjutnya untuk mengukur daya ledak otot tungkai menggunakan vertical jump test dan instrumen motivasi berprestasi menggunakan instrumen tes berupa kuesioner dalam bentuk pertanyaan yang berpedoman pada skala likert yang diuji cobakan pada 15 atlet. Untuk melihat validitas menggunakan rumus product moment. Selanjutnya untuk melihat reliabelitas menggunakan rumus alpha cronbach. Data yang dikumpulkan akan dianalisis melalui uji persyaratan analisis yang terdiri dari uji normalitas dan 
uji homogenitas, kemudian uji Linearitas dan signifikan regresi, dan analisis jalur.

\section{HASIL}

Berdasarkan data hasil penelitian mengenai Keterampilan smash bolavoli diperoleh skor terendah 125,52, skor tertinggi 173,27 , sehingga diperoleh rentang 47,75. Selanjutnya, diperoleh rata-rata 152,105 varians 177,3681 dan simpangan baku sebesar $13,-31796$.

Pengujian hipotesis yang hasilnya sebagai berikut pengaruh koordinasi matatangan terhadap keterampilan smash sebesar 3,357. pengaruh daya ledak otot tungkai terhadap keterampilan smash sebesar 2,740. pengaruh motivasi terhadap keterampilan smash sebesar 4,106. pengaruh koordinasi mata-tangan terhadap motivasi berprestasi sebesar 4,404. pengaruh daya ledak otot tungkai terhadap motivasi berprestasi sebesar 0,419 .

Terdapat pengaruh langsung antara koordinasi mata dan tangan terhadap keterampilan smash pada atlet klub bolavoli, terdapat pengaruh langsung antara daya ledak otot tungkai terhadap keterampilan smash bolavoli, terdapat pengaruh langsung antara motivasi berprestasi terhadap keterampilan smash bolavoli, terdapat pengaruh langsung antara koordinasi mata-tangan terhadap motivasi berprestasi dan terdapat pengaruh langsung antara koordinasi matatangan terhadap motivasi berprestasi. Implikasi dari penelitian ini terdiri dari implikasi penelitian yaitu penelitian ini dapat dijadikan dasar untuk meneliti lebih lanjut yang berkenaan dengan variabel-variabel didalamnya. selanjutnya, implikasi teoritis yaitu hasil penelitian menunjukkan terdapat pengaruh antara variabel independen terhadap variabel dependen dan implikasi praktis yaitu strategi melatih dan pembuatan program latihan dapat pelatih sesuaikan dengan kondisi siswa sebagai penerapan cara-cara untuk tercapainya tujuan.

\section{PEMBAHASAN}

\section{Pengaruh Koordinasi Mata-Tangan terhadap smash Bolavoli.}

Salah satu faktor penetu untuk melakukan smes bolavoli adalah koordinasi mata-tangan. koordinasi mata tangan mempunyai hubungan signifikan dengan kemampuan ketepatan servis atas bolavoli (Juita dkk, 2013). Koordinasi mata-tangan mem- punyai hubungan yang berarti dengan kemampuan smashatlet bolavoli (Saputra, 2015). Gerakan servis atas memiliki karakteristik yang sama dengan pukulan smash. Dapat disimpulkan bahwa koordinasi mata-tangan memiliki kontribusi signifikasn terhadap smash. Koordinasi mata-tangan berbanding lurus dengan tingkat kemampuan smash Bolavoli.

\section{Pengaruh Daya Ledak Otot Tungkai terhadap smash bolavoli.}

Aspek fisik yang berkontribusi signifikan dalam smash bolavoli adalah daya ledak otot tungkai. Ada kontribusi daya ledak otot tungkai dengan kemampuan smash dalam permainan bolavoli (Kedo, 2013). Daya ledak mempengaruhi tinggi loncatan dari pemain. Dalam melakukan smash pemain harus melakukan loncatan semaksimal mungkin untuk melakukan serangan ke daerah lawan. Seorang pemain dalam melakukan smash harus dapat melampaui tinggi net $2,43 \mathrm{~m}$ untuk putra dan 2,24 untuk putri, sehingga semakin baik daya ledak otot tungkai maka akan menambah tinggiloncatan.

Pengaruh Motivasi Berprestasi terhadap smash bolavoli.

Motivasi berprestasi pada hakikatnya merupakan keinginan, hasrat, kemauan, dan pendorong untuk dapat unggul yaitu mengungguli prestasi yang pernah dicapai sendiri atau orang lain Husdarta (2010). Motivasi berprestasi yang tinggi tidak hanya dibutuhkan dalam pembinaan dan latihan teknik saja, akan tetapi diperlukan dalam semua proses pembinaan dan latihan untuk meraih suatu prestasi.

Perbedaan Pengaruh Koordinasi MataTangan, Daya Ledak Otot Tungkai terhadap Motivasi Berprestasi

Prestasi dalam olahraga merupakan capaian performa tertentu yang dapat diwujudkan oleh kapasitas performansi dari tubuh. Faktor prestasi seorang atlet dipengaruhi oleh berbagai asktorpek. Adapun faktor prestasi dalam olahraga antara lain Fisik, Teknik, Taktik dan Kematangan Mental. Faktor fisik merupakan faktor yang paling fundamental dalam performa olahraga. Dasar meningkatnya faktor yang lain dipengaruhi oleh kapasitas kerja isik yang mumpuni. Kapasitas kerja fisik secara tidak langsung mempengaruhi mental dan moti- 
vasi seseorang untuk mewujudkan kemampuan maksimal.

\section{KESIMPULAN}

Kesimpulan dari penelitian ini antara lain: (1) Terdapat pengaruh signifikan antara koordinasi mata-tangan terhadap kemampuan smash bolavoli, (2) Terdapat pengaruh signifikan antara daya ledak otot tungkai terhadap kemampuan smash bolavoli, (3) Terdapat pengaruh signifikan antara motvasi berprestasi terhadap kemampuan smash bolavoli, serta (4) Terdapat pengaruh signifikan antara koordinasi matatangan dan daya ledak otot tungkai terhadap motivasi berprestasi dari atlet. bola voli pada club voli kecamatan lore tengah desa lempe. Tadulako journal sport sciences and physical education, 1(5).

Kenny, B., \& Gregory, C. (2006). Volleyball: Steps to success. Human Kinetics.

Magil, R dan David A, 2015. Motor Learning and Control Conseps and Aplication, New York: McGraw Gill.

Saputra, A. 2015. Kontribusi daya ledak otot tungkai dan koordinasi matatangan terhadap kemampuan smash atlet bolavoli sma negeri 1 linggo sari baganti. Jurnal pendidikan jasmani kesehatan dan rekreasi, 1(1).

\section{DAFTAR PUSTAKA}

Syafruddin. 2012. Dasar-Dasar Kepelatihan

Beutelstahl, D. (2005). Belajar Bermain Bola Volley. Bandung, Pioneer.

Tangkudung, J. 2012. Kepelatihan Olahraga, Jakarta: Cerdas Jaya.

Dany, M. M., Hariyanto, e., \& Hariyoko,

H. 2016. Pengaruh kombinasi latihan Widiastuti. 2015. Tes dan Pengukuran power tungkai terhadap peningkatan Olahraga. Jakarta: RajaGrafindo keterampilanpassing bagi peserta kegiatan ekstrakurikuler sepakbola smpn 21 malang. Jurnal pendidikan jasmani, 26(1).

Edward, H. William. 2010. Motor Learning and Control From theory To Practice, USA: Cenggage Learning.

Giriwijoyo, S dan Dikdik Z. Sidik. 2012. Ilmu Faal Olahrga (Fisiologi Olahrga), Bandung: Remaja Rosdakarya,.

Hanif, A. S. 2015. Kepelatihan Dasar Sepak Takraw, Jakarta: Raja Grafindo Persada

Husdarta. 2010. Psikologi olahraga, Bandung: Alfabeta.

Juita, A. 2014. Kontribusi daya ledak otot lengan dan koordinasi mata tangan terhadap ketepatan servis atas bolavoli mahasiswa pendidikan kepelatihan olahraga universitas riau. Primary, 2(02), 25-33.

Kedo, E. F. 2014. Kontribusi kelentukan togok, daya ledak otot tungkan dan kekuatan otot lengan terhadap kemampuan smash dalam permainan 